\title{
Transcriptome analysis reveals the molecular mechanisms of heterosis on thermal resistance in hybrid abalone
}

\author{
Qizhen Xiao ${ }^{1,2 \dagger}$, Zekun Huang ${ }^{1,2 \dagger}$, Yawei Shen ${ }^{1,2}$, Yang Gan ${ }^{1,2}$, Yi Wang ${ }^{1,2}$, Shihai Gong ${ }^{1,2}$, Yisha Lu ${ }^{1,2}$, Xuan Luo ${ }^{1,2}$,
} Weiwei $\mathrm{You}^{1,2^{*}}$ and Caihuan $\mathrm{Ke}^{1,2^{*}}$

\begin{abstract}
Background: Heterosis has been exploited for decades in different animals and crops due to it resulting in dramatic increases in yield and adaptability. Hybridization is a classical breeding method that can effectively improve the genetic characteristics of organisms through heterosis. Abalone has become an increasingly economically important aquaculture resource with high commercial value. However, due to changing climate, abalone is now facing serious threats of high temperature in summer. Interspecific hybrid abalone (Haliotis gigantea $q \times H$. discus hannai $\hat{\partial}, \mathrm{SD}$ ) has been cultured at large scale in southern China and has been shown high survival rates under heat stress in summer. Therefore, SD has become a good model material for heterosis research, but the molecular basis of heterosis remains elusive.
\end{abstract}

Results: Heterosis in thermal tolerance of SD was verified through Arrhenius break temperatures (ABT) of cardiac performance in this study. Then RNA-Sequencing was conducted to obtain gene expression patterns and alternative splicing events at control temperature $\left(20^{\circ} \mathrm{C}\right)$ and heat stress temperature $\left(30^{\circ} \mathrm{C}\right)$. A total of $356(317$ genes), 476 (435genes), and 876 (726 genes) significantly diverged alternative splicing events were identified in $\mathrm{H}$. discus hannai (DD), H. gigantea (SS), and SD in response to heat stress, respectively. In the heat stress groups, $93.37 \%(20,512$ of 21,969$)$ of the expressed genes showed non-additive expression patterns, and over-dominance expression patterns of genes account for the highest proportion (40.15\%). KEGG pathway enrichment analysis showed that the overlapping genes among common DEGs and NAGs were significantly enriched in protein processing in the endoplasmic reticulum, mitophagy, and NF-kB signaling pathway. In addition, we found that among these overlap genes, 39 genes had undergone alternative splicing events in SD. These pathways and genes may play an important role in the thermal resistance of hybrid abalone.

Conclusion: More alternative splicing events and non-additive expressed genes were detected in hybrid under heat stress and this may contribute to its thermal heterosis. These results might provide clues as to how hybrid abalone has a better physiological regulation ability than its parents under heat stress, to increase our understanding of heterosis in abalone.

Keywords: Heterosis, Abalone, Heat stress, Transcriptome, Alternative splicing, Non-additive expression

\footnotetext{
* Correspondence: wwyou@xmu.edu.cn; chke@xmu.edu.cn

${ }^{\dagger}$ Qizhen Xiao and Zekun Huang contributed equally to this work.

'State Key Laboratory of Marine Environmental Science, College of Ocean

and Earth Sciences, Xiamen University, Xiamen 361102, People's Republic of

China

Full list of author information is available at the end of the article
}

(c) The Author(s). 2021 Open Access This article is licensed under a Creative Commons Attribution 4.0 International License, which permits use, sharing, adaptation, distribution and reproduction in any medium or format, as long as you give appropriate credit to the original author(s) and the source, provide a link to the Creative Commons licence, and indicate if changes were made. The images or other third party material in this article are included in the article's Creative Commons licence, unless indicated otherwise in a credit line to the material. If material is not included in the article's Creative Commons licence and your intended use is not permitted by statutory regulation or exceeds the permitted use, you will need to obtain permission directly from the copyright holder. To view a copy of this licence, visit http://creativecommons.org/licenses/by/4.0/ The Creative Commons Public Domain Dedication waiver (http://creativecommons.org/publicdomain/zero/1.0/) applies to the data made available in this article, unless otherwise stated in a credit line to the data. 


\section{Background}

Heterosis, or hybrid vigor, refers to the phenomenon in which hybrid offspring surpass their parents in the desired character [1]. A batch of hybrid livestock (e.g., pig) and crops (e.g., rice) have shown better performance in growth and environmental adaptation when compared with their parents, therefore it has received extensive research [2]. Various genetic models have been put forward to explain heterosis, including dominance, overdominance, and epistatic hypothesis [3]. Recently, the overdominance hypothesis has been supported by a lot of experimental research [4-6], in which nonadditive effects are described as a consequence of genetic differences between the homozygous parents and their heterozygous hybrids [7]. The discussion of the genetic basis of heterosis has lasted for nearly a century, but that of the molecular mechanism of heterosis still remain elusive Next-generation sequencing (NGS) technologies offer the potential to uncover the molecular mechanism of heterosis at the transcriptional level [8]. The identification of non-additive genes is accomplished based on their expression patterns which may finally shape complex traits of hybrid organisms. Genome-wide changes in gene expression have been documented in hybrids of maize [9], rice [10], soybean [11], wheat [12], cotton [13], yellow catfish [14], pearl oyster [15], pufferfish [16], sea cucumber [17] and black seabream [18]. Transcriptomic analysis provides an efficient way to explore heterosis, and its results mainly include abundant differential expressed genes and alternative splicing (AS) events. AS refers to the regulatory processes to produce variably spliced mRNAs by selecting various combinations of splice sites within a pre-mRNA in eukaryotes. In humans, approximately $98 \%$ of multi-exonic genes are alternatively spliced, and alternative splicing producce diverse transcripts and proteins [19]. AS can significantly impact the transcriptome and proteome by creating multiple isoforms that can maintain the diversity of protein in eukaryotes [20]. Five AS events types have been recognized in animals, including skipped exons (SE), alternative 5'splice sites (A5SS), alternative 3'splice sites (A3SS), retained introns (RI), and mutually exclusive exons (MXE) [21]. As a post-transcriptional regulation process modulating gene expression, AS has been reported to play an important role in heterosis establishment [22].

Abalone has become an increasingly economically important aquaculture resource with high commercial value. However, ocean warming is predicted to greatly affect marine ecosystems [23], this seriously affected the abalone farming industry. Elevated temperature can increase oxygen consumption of aquatic animals, largely influencing the most metabolic processes in ectotherms [24]. Harmful end-products, such as reactive oxygen species (ROS), would also be produced and cumulated under heat stress [25]. In recent years, the abalone farming industry has experienced a notable expansion in China, whose yield accounting for more than $90 \%$ of the global aquaculture production (FAO, 2019). The Pacific abalone Haliotis discus hannai (DD), the main aquaculture abalone species in China, is naturally distributed in temperate water [26]. Due to the natural climate conditions in Fujian Province (the main abalone producing area in China), Pacific abalone is now facing serious threats of high temperature in summer. This pattern is exacerbated by increasingly serious global climate change [23]. To resolve this problem, new abalone species that can withstand high temperatures were introduced to China. The Xishi abalone $H$. gigantea (SS), which is naturally distributed along the coasts of Japan, has a wide range of temperature adaptability [27]. The hybrid $H$. gigantea $\bigcirc \times H$. discus hannai $\widehat{o}(\mathrm{SD})$ was produced on large-scale and has been approved to exhibit heterosis in growth rate, survival rate, sub-low salinity adaptability, and thermal resistance [27-29]. Therefore, $\mathrm{SD}$ is a good model for heterosis research, the molecular basis of which remains elusive.

The objective of this study is to uncover the molecular mechanisms underlying the high superiority of temperature resistance in an interspecific hybrid. Thermal tolerance of hybrid (SD) and its parents (SS and DD) was first assessed through ABT measurements, to validate the heterosis of SD at physiological levels. Then RNA-Sequencing (RNA-Seq) was conducted to obtain gene expression patterns and alternative splicing events. These results might provide clues as to how hybrid abalone has a better physiological regulation ability than its parents under thermal stress, which also increase our understanding of heterosis in abalone.

\section{Results}

\section{The comparison of growth traits}

At the beginning of the breeding experiment, the three populations were not significantly different $(P>0.05)$ in shell length and total weight. After seven months, the shell lengths of DD, SS and SD abalones were 37.69 \pm $0.51,32.72 \pm 0.89$, and $42.80 \pm 1.37 \mathrm{~mm}$, respectively. The average weights of DD, SS and SD abalones were $7.69 \pm$ $0.35,4.37 \pm 0.45$, and $9.10 \pm 1.06 \mathrm{~g}$, respectively. The shell length and total weight of SD abalone were significantly higher than its parents $(P<0.05)$. The survival rate of SD was higher than that of DD and SS during hightemperature months (July to September) (Fig. 1).

\section{ABT measurement of cardiac performance}

$\mathrm{ABT}$ s of $\mathrm{DD}, \mathrm{SS}$ and SD were $30.66 \pm 0.8^{\circ} \mathrm{C}, 31.87 \pm$ $0.59^{\circ} \mathrm{C}$ and $32.38 \pm 0.71{ }^{\circ} \mathrm{C}$, respectively (Fig. 2A). ABTs of SD were significantly higher than those of DD and SS 

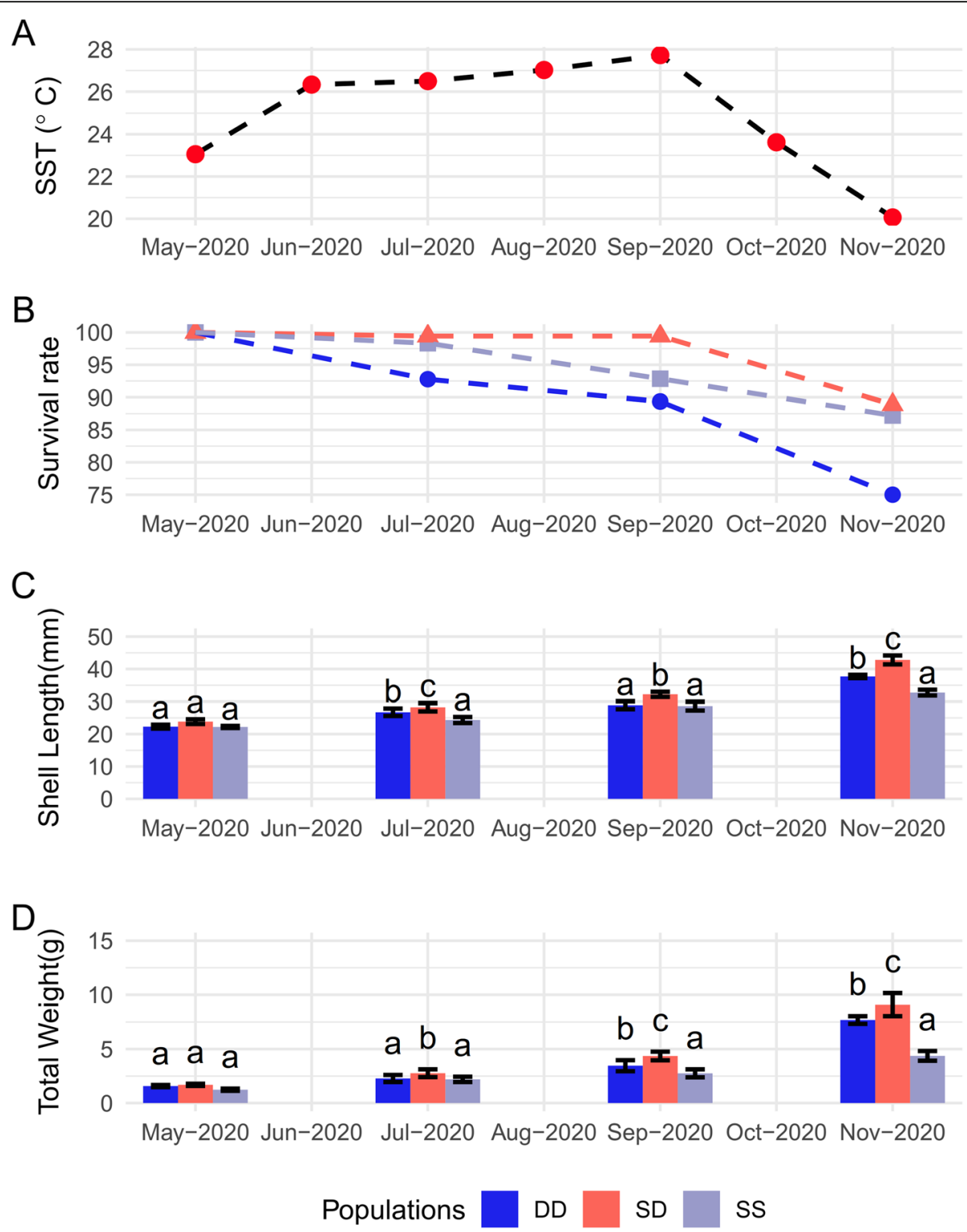

Fig. 1 (A) The seawater surface temperature. (B) The survival rate of three abalone populations from May 2020 to Nov 2020. (C) The shell length of three abalone populations from May 2020 to Nov 2020. (D) The total weight of three abalone populations from May 2020 to Nov 2020. Different letters represent the significant difference among three populations $(P<0.05)$

$(P<0.05)$. The hybrid abalone SD exhibited the best thermal tolerance, while DD was shown to be most sensitive to heat stress, indicating the heterosis of thermal resistance in hybrid SD.

\section{Transcriptome sequencing and identification of DEGs}

In total, an average of 43.65 million raw reads per specimen (40.89-47.38 million raw reads) were obtained through RNA-sequencing. Then 39.22-44.99 million clean reads were filtered from each sequencing sample, while $71.66-88.11 \%$ of the reads were aligned to the reference genome. A principal component analysis (PCA) based on the whole genome gene expression profiles showed that six groups (3 populations $\times 2$ treatment groups) clearly separated in the $\mathrm{PC} 1 \times \mathrm{PC} 2$ score plot (Fig. 2B), with $\mathrm{PC} 1$ explaining $29 \%$ and $\mathrm{PC} 2$ explaining $25 \%$ of the total variance.

Between the $\mathrm{C}$ and $\mathrm{H}$ groups, a total of 3880 DEGs in SS (referred to as "SS_CvsH"), 4436 DEGs in DD (referred to as "DD_CvsH"), and 3713 DEGs in SD (referred to as "SD_CvsH") (Fig. 3B) were identified, with 1966 DEGs common to all three comparisons. Among these DEGs, 573, 1291, and 985 genes were specifically expressed in SD, DD, and SS. In addition, the numbers of overlap DEGs between SD_CvsH and DD_CvsH, SD_ CvsH and SS_CvsH, and DD_CvsH and SS_CvsH were 

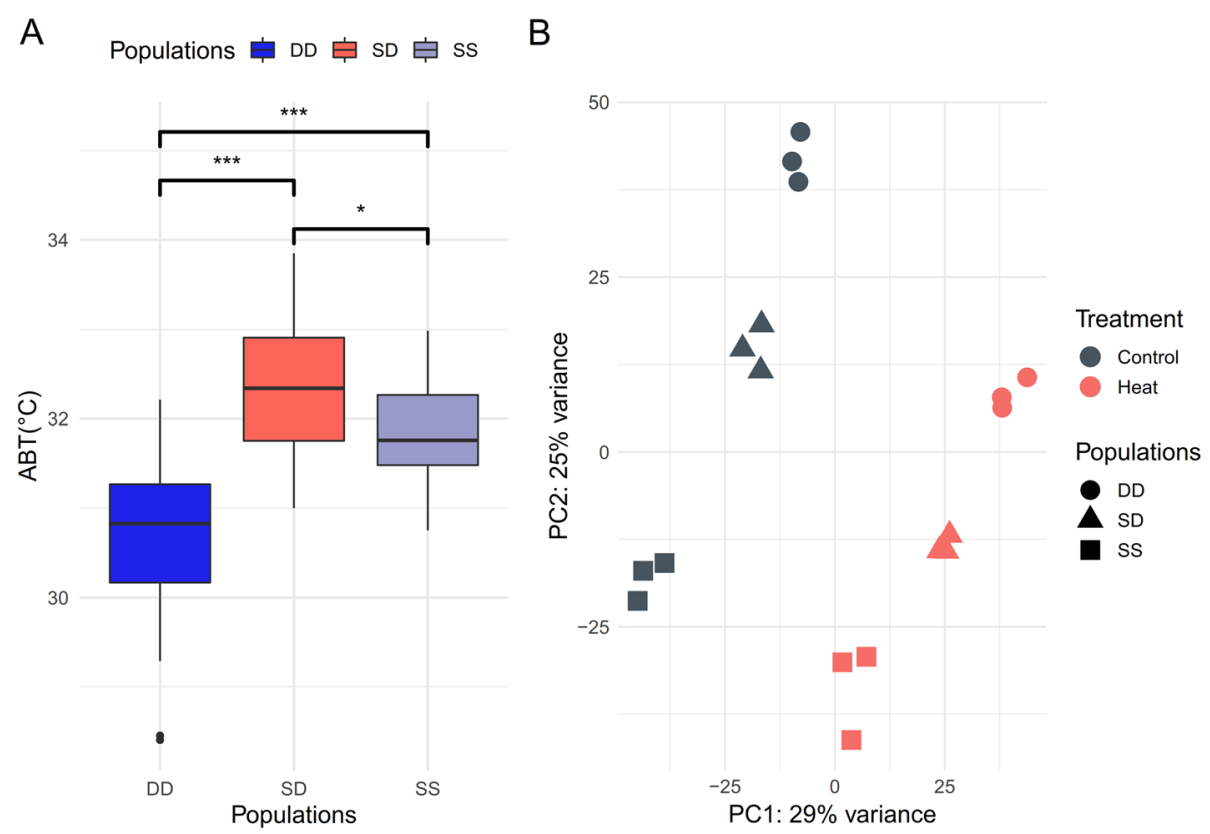

Fig. 2 (A) The comparisons of thermal tolerance in three abalone populations base on ABT. *indicates $P<0.05$; $* * * i n d i c a t e s ~ P<0.01$. (B) Principal component analysis plot based on the whole genome gene expression profiles

2663, 2413, and 2448, respectively. Among the DEGs, the number of down-regulated genes was higher than the number of up-regulated genes (Fig. 3A). The results of KEGG pathway enrichment analysis showed that those 1966 common DEGs in three populations were enriched in the following pathways: protein processing in endoplasmic reticulum (57 genes), NF- $\kappa \mathrm{B}$ signaling pathway ( 25 genes), antigen processing and presentation (16 genes), osteoclast differentiation (22 genes), Toll and Imd signaling pathway (27 genes), fluid shear stress and atherosclerosis (32 genes), necroptosis (30 genes), and apoptosis (19 genes) (Fig. 3C). And these 573 specifically expressed DEGs in SD enriched in the following pathways: arginine and proline metabolism (9 genes), MAPK signaling pathway (7 genes), lysosome (18 genes), tryptophan metabolism (8 genes), cysteine and methionine metabolism (9 genes), glutathione metabolism (7 genes) (Fig. 3D).

The interaction analysis between population and environment was carried out using $\mathrm{R}$ DESeq 2 package with padj $<0.05$ and $\mid \log 2$ FoldChange $\mid>1$ as the significance threshold to estimate the interaction effect on gene expression. The results showed that there were 143 significantly different genes in the comparison of "(heat SScontrol SS) - (heat SD-control SD)", and 26 significantly different genes in the comparison of "(heat DD-control DD) - (heat SD-control SD)", and 236 significantly different genes in the comparison of "(heat SS-control SS) (heat DD-control DD)". There were a total of 261 DEGs influenced by interaction effects from population and environment. These genes were related to endocrine resistance, apoptosis, Toll and Imd signaling pathway, MAPK signaling pathway, and cytokine-cytokine receptor interaction.

\section{Expression patterns of non-additive genes}

A total of $91.98 \%(20,206$ of 21,969$)$ of the genes detected in the $\mathrm{C}$ groups of three populations showed nonadditive expression patterns (Fig. 4A), classified into six distinct classes: high-parent dominance (HPD), lowparent dominance (LPD), under-dominance (UDO), over-dominance (ODO), negative partial-dominance (NPD), and positive partial-dominance (PPD). Of 20,206 genes, 1354 (6.70\%), 1559(7.72\%), 7061 (34.94\%), 5590 (27.67\%), $2280(11.28 \%)$ and 2362(11.69\%) showed HPD, LPD, ODO, UDO, PPD, and NPD, respectively. ODO and UDO accounted for more than half of non-additive genes (Fig. 4B). The results of KEGG enrichment pathway analysis showed that 7061 ODO genes enriched in the following pathways: sphingolipid signaling pathway (65 genes), TNF signaling pathway (61 genes), apoptosis (95), chemokine signaling pathway (57 genes), EGFR tyrosine kinase inhibitor resistance (45 genes), and autophagy (71 genes) (Fig. 4C). The results of KEGG enrichment pathway analysis showed that those 5590 UDO genes enriched in the following pathways: oxidative phosphorylation (71 genes), thermogenesis (114 genes), citrate cycle (TCA cycle) (27 genes), protein processing in endoplasmic reticulum (84 genes), glycolysis/ 


\section{A}

\section{B}
Stat $\square$ Down regulated $\square$ Up regulated
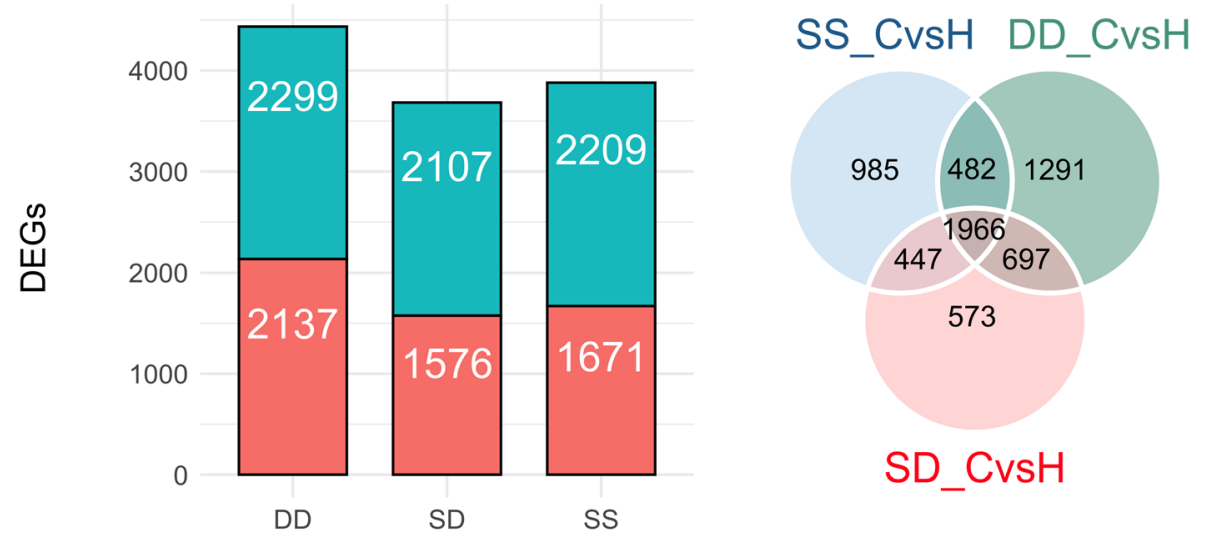

C

D
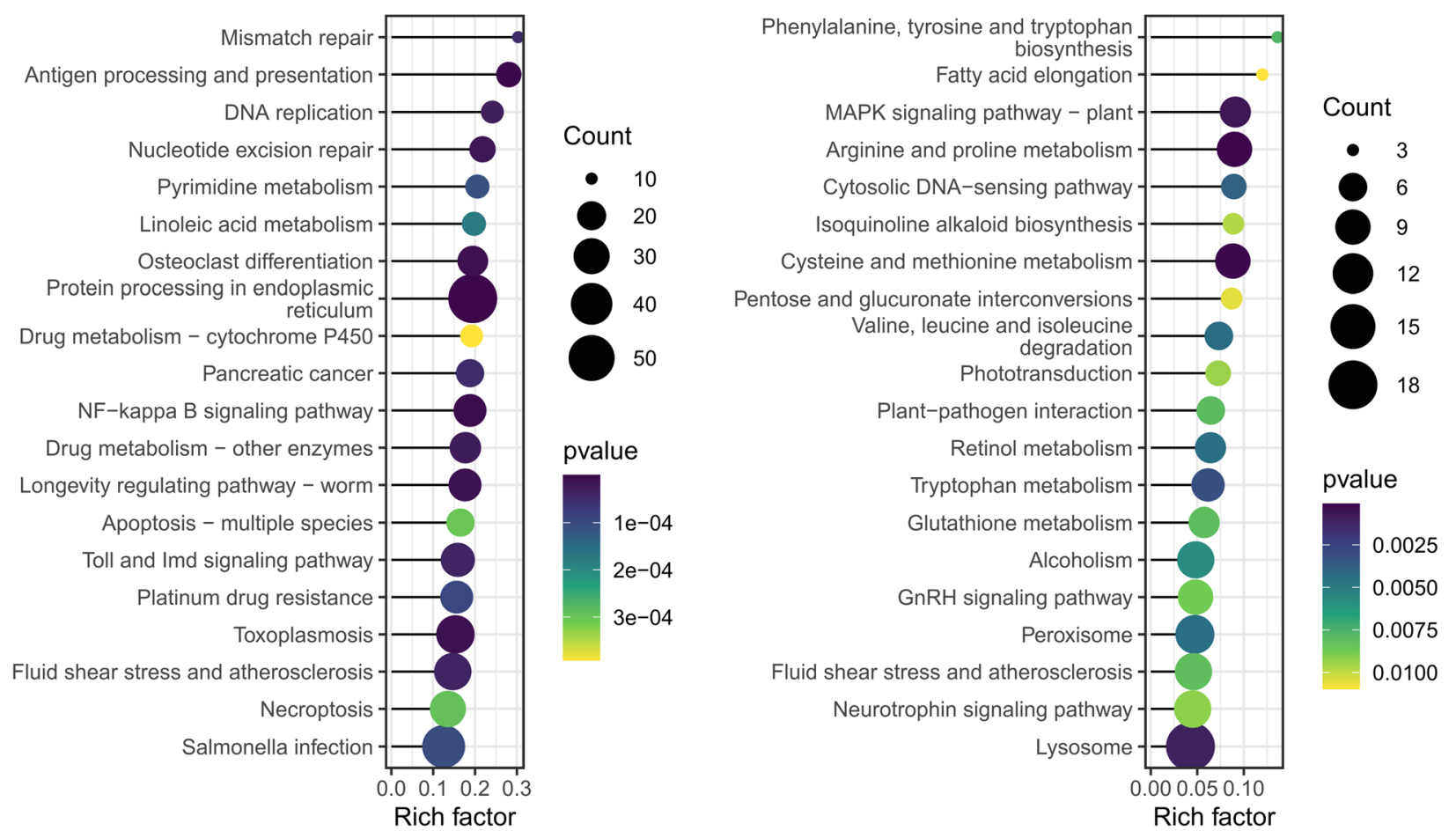

Fig. 3 (A) Up- and down-regulated DEGs in three populations. (B) The Venn diagram of significant differently expressed genes (DEGs) in three abalone populations. DD_CvsH: the DEGs between the control group and heat stress group in DD. SS_CvsH: the DEGs between the control group and heat stress group in SS. SD_CvsH: the DEGs between the control group and heat stress group in SD. (C) Top 20 KEGG enrichment pathways of the common DEGs shared by SD, SS, and DD. (D) Top 20 KEGG enrichment pathways of the specifically expressed DEGs in SD compared to the SS and DD

gluconeogenesis (25 genes), basal transcription factors (23 genes), and glucagon signaling pathway (46 genes).

A total of $93.37 \%(20,512$ of 21,969$)$ of the genes detected in the $\mathrm{H}$ groups of three populations showed non-additive expression patterns (Fig. 4D). Of 20,512 genes, 1119 (5.46\%), 1278 (6.23\%), 8235 (40.15\%), 5819
(28.37\%), 2047 (9.98\%) and 2014 (9.82\%) showed HPD, LPD, ODO, UDO, PPD, and NPD, respectively. ODO account for the highest proportion, more than $40 \%$ of non-additive genes (Fig. 4E). The results of KEGG enrichment pathway analysis showed that 8235 ODO genes enriched in the following pathways: phospholipase D 


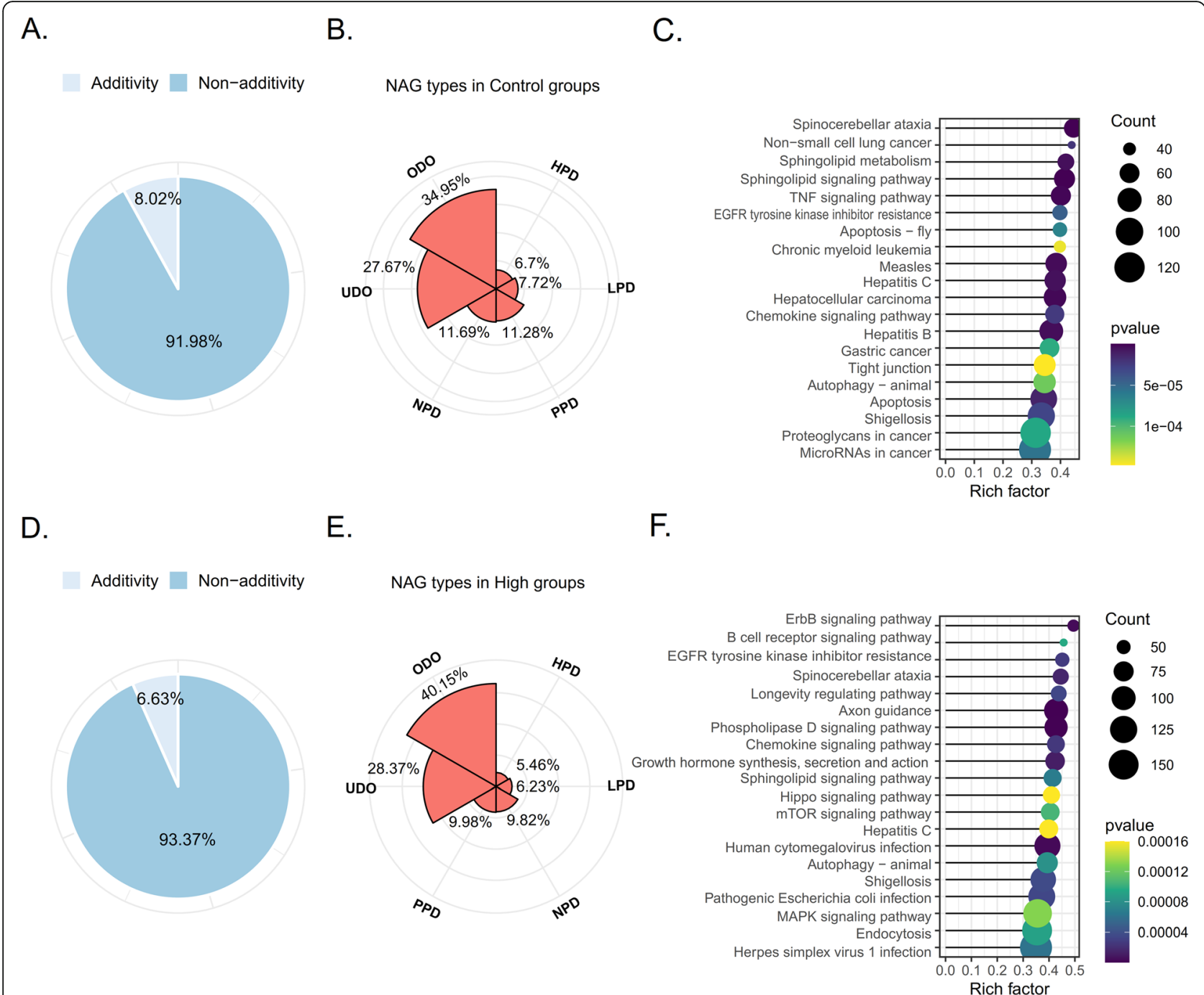

Fig. 4 (A) The proportion of additivity and non-additivity genes in control groups. (B) The proportion of expression pattern for non-additively genes in control groups. (C) Top 20 KEGG enrichment pathways of the over-dominance in control group. (D) The proportion of additive and nonadditive genes in heat stress groups. (E) The proportion of expression pattern for non-additively genes in heat stress group. (F) Top 20 KEGG enrichment pathways of the over-dominance in heat stress group. HPD: high-parent dominance, LPD: low-parent dominance, UDO: underdominance, ODO: over-dominance, NPD: negative partial-dominance, PPD: positive partial-dominance

signaling pathway (94 genes), axon guidance (100 genes), growth hormone synthesis, secretion and action (72 genes), chemokine signaling pathway (64 genes), EGFR tyrosine kinase inhibitor resistance (51 genes), autophagy (149 genes), B cell receptor signaling pathway (42 genes), and mTOR signaling pathway (68 genes) (Fig. 4F). The results of KEGG enrichment pathway analysis showed that 5819 UDO genes enriched in the following pathways: ribosome (117 genes), oxidative phosphorylation (80 genes), metabolism of xenobiotics by cytochrome P450 (40 genes), thermogenesis (118 genes) RNA transport (98 genes), and ribosome biogenesis in eukaryotes (61 genes).

\section{Identification of AS events}

The divergence of AS events between the $\mathrm{C}$ and $\mathrm{H}$ group among three populations were characterized. For a total of 356 (317 genes), 476 (435 genes), and 876 (726 genes) significant divergence AS events were identified in $\mathrm{DD}, \mathrm{SS}$, and SD, respectively (Fig. 5A-5C). The hybrid SD exhibited the most dramatic AS events and genes in response to heat stress, comparing with its parent SS and DD species. These divergence AS events included skipping exons (90.03-91.73\%) and mutually exclusive exons (8.27-9.97\%). The results of KEGG pathway enrichment analysis showed that 317 DAS genes in DD enriched in the following pathways: 


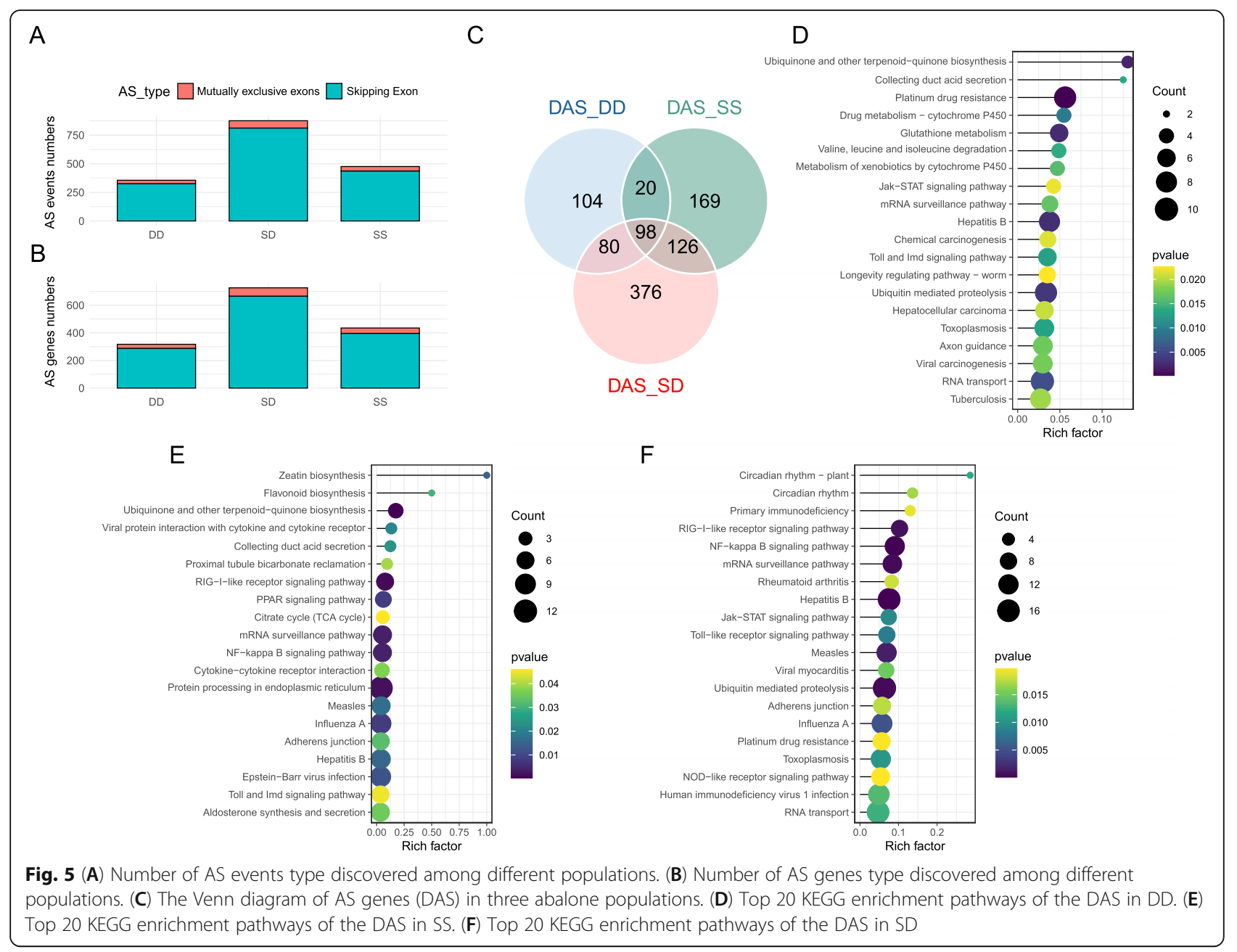

ubiquitin mediated proteolysis (9 genes), RNA transport (10 genes), glutathione metabolism (6 genes), and Toll and Imd signaling pathway (6 genes) (Fig. 5D). The results of KEGG pathway enrichment analysis showed that 435 DAS genes in SS enriched in the following pathways: protein processing in endoplasmic reticulum (12 genes), NF- $\kappa$ B signaling pathway (7 genes), RIG-I-like receptor signaling pathway (6 genes), and mRNA surveillance pathway (7 genes) (Fig. 5E). The results of KEGG pathway enrichment analysis showed that 726 DAS genes in SD enriched in the following pathways: ubiquitin mediated proteolysis (17 genes), NF- $\kappa$ B signaling pathway (12 genes), Toll-like receptor signaling pathway (8 genes), RNA transport (16 genes), and NOD-like receptor signaling pathway (10 genes) (Fig. 5F).

\section{Integrated analysis of DEGs, DAGs, and NAGs}

First, the common DEGs of three populations ("Common_DEGs") and ODO genes of heat stress group ("H_ ODO_NAGs") were analyzed. There were 545 common genes between "Common_DEGs" and "H_ODO_NAGs". The results of KEGG enrichment pathway analysis showed that those genes enriched in: protein processing in endoplasmic reticulum (19 genes), NF- $\kappa \mathrm{B}$ signaling pathway (8 genes), and mitophagy (7 genes) (Fig. 6D). In addition, we found that among these 545 genes, 39 genes had undergone alternative splicing event in SD ("SD_ DAGs") (Fig. 6A), and the expression levels of these genes in each group were shown in the Fig. $6 \mathrm{C}$. These genes including $R e l$ (Nuclear factor NF- $k \mathrm{~B}$ p110), SYK (Tyrosine-protein kinase SYK), SCARB1 (Scavenger receptor class B member 1), TLR1(Toll-like receptor 1), and MUC1(Mucin-1). Alternative splicing of TLR1 gene in SD were shown in Fig. 6B. These genes may play an important role in the thermal resistance of hybrid abalone.

\section{Discussion}

In this study, ABT was used to evaluate and compare the thermal resistance of abalones DD, SS, and their hybrid SD. The heterosis in thermal tolerance of hybrid SD was verified through $\mathrm{ABT}$ of cardiac performance ABTs of SD were significantly higher than those of DD and SS. Therefore, SD is a good model for further 


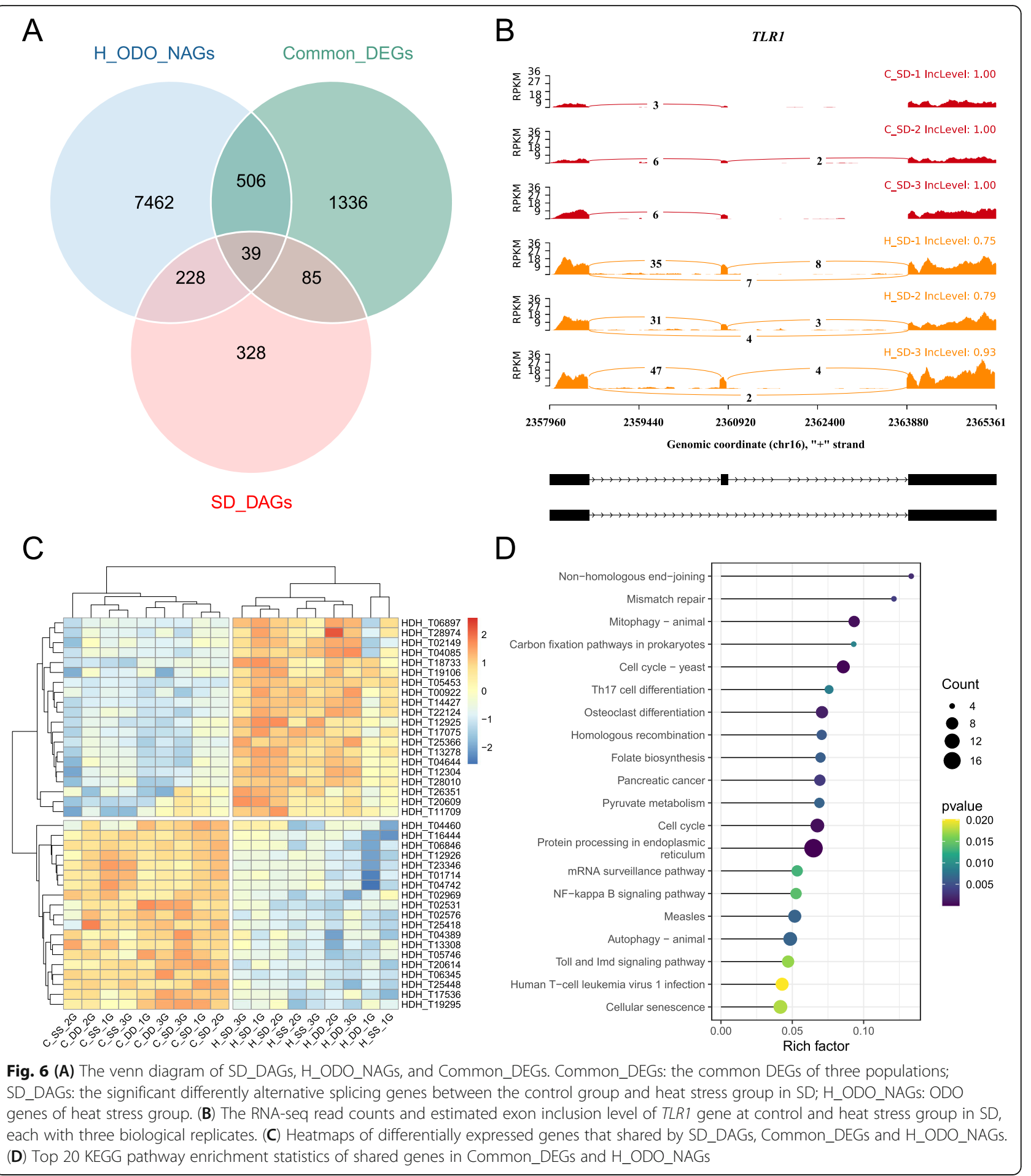

studying heterosis in thermal tolerance of abalone. According to the results of $\mathrm{ABT}$, the thermal resistance of SD was increased by $0.51{ }^{\circ} \mathrm{C}$ and $1.72{ }^{\circ} \mathrm{C}$ compared with SS and DD. The result is consistent with our previous studies, in which the better thermal resistance of SD was confirmed by the results of $\mathrm{LT}_{50}$, Kaplan-Meier cumulative survival curves, CTM, ABT, survival, and growth rate [28]. The average sea surface temperatures have increased by $0.6{ }^{\circ} \mathrm{C}$ in the last century and global temperature are predicted be increase at least $2{ }^{\circ} \mathrm{C}$ in the next 50 years [30]. A rise in thermal resistance of $1{ }^{\circ} \mathrm{C}$ could play a crucial role in abalone's survival in the future world. In addition, SD also has super-parent heterosis in growth traits (Fig. 1C and D). After seven months 
of culture, SD exhibited significant growth and survival advantages over DD and SS, especially in hightemperature months (Fig. 1B). This result is consistent with the result of $\mathrm{ABT}$ that SD has better temperature resistance. Some studies also have been conducted to obtain hybrid abalones with better environmental adaptability: $H$. rufescens $+9 \times H$. corrugate $\widehat{\partial}[31], H$. gigantea

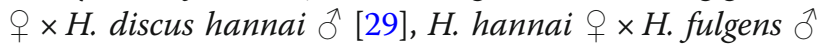
$[29,32], H$. rubra $O \times H$. laevigata $\delta$ [33]. However, none of the molecular mechanisms explain heterosis in abalone, which is compounded by complex allelic and genic interactions, and epigenetic regulation. Over the years, a lot of efforts have been made in exploring the intricate molecular basis of heterosis [34, 35], benefiting from the development of high-throughput sequencing technology. The number of DEGs between the $\mathrm{C}$ and $\mathrm{H}$ group in SD was less than its parents, possibly because the thermal-tolerant SD remained relatively stable under environmental heat stress. In the study of hybrid abalone [33], the heart rates and metabolic rates of the hybrid abalone were more stable at high temperatures than its parents, suggesting that hybrids were less sensitive to the changes in temperatures. This higher transcriptome variation in the thermal-sensitive populations has occurred in other species, including the Pacific abalone $(H$. discus hannai) [26], greenlip abalone (H. laevigata) [36], snail (Chlorostoma funebralis) [37], and redband trout (Oncorhynchus mykiss gairdneri) [38]. AS events can be considered as a post-transcriptional regulation that acts as an effective strategy to mediate complex biological processes [39]. It is known to change protein function by altering signals for trafficking, phosphorylation, and glycosylation [40]. It is a key player in response to abiotic stresses, including the heat stress [41]. In this study, much more AS events were discovered in SD (876), comparing with its parents (356 in DD and 476 in SS), suggesting that hybridization may bring more AS potential. These AS events were from 726 genes in SD, accounting for $3.30 \%$ of the genes in the whole transcriptome. However, only 1.98 and $1.44 \%$ of the transcripts were detected to be involved in the AS events in SS and DD, respectively. This indicated that the involvement of alternative splicing in the gene expression regulations and phenotypic variations in hybrid abalone SD [42]. Similarly, there were more AS events in the heat tolerant catfish than in the intolerant catfish. In heat-intolerant catfish, the thermal stress induced 29.2\% increases in alternative splicing events and $25.8 \%$ increases in alternatively spliced genes [43]. In the hybrid poplar (Populus alba $+\times P$. glandulosa $\hat{\jmath}$ ), it was found that the proportion of alternatively spliced genes in hybrid was higher than that of the parent, therefore the more isoforms caused by AS contributed more for the hybrid's growth [44].
According to the difference in genes expression between hybrids and that its parents, gene expression patterns can be divided into additive or non-additive expression [45]. The complementation of additive and non-additive genetic effects was the genetic basis of hybrid traits. Variations in the expressions of the additive and non-additive genes are more correlated with genetic distance than with genome dosage, and the expression of the non-additive genes is more common in the interspecific hybrids than in the intraspecific hybrids $[46,47]$. In this study, the gene expression patterns of hybrid abalone and its parents were analyzed. The results showed that the non-additive genes accounted more than $90 \%$ of the total genes. ODO and UDO accounted for the highest proportion, more than half of non-additive genes. This suggests that the non-additive effects may contribute more than the additive effects in heterosis of thermal resistance in SD. This conclusion in similar to our previous research, compared to purebred, most stressinduced proteins of hybrids abalone exhibited overdominance by proteomic analysis, and this may have been related to disease resistance [48]. Also, this conclusion as shown in other heterosis studies of hybrids, including maize [49], Arabidopsis [50], clam [51], oyster [52].

Based on the integrated analysis of DEGs, DAGs, and NAGs, pathways including protein processing in endoplasmic reticulum, mitophagy, and NF- $\kappa \mathrm{B}$ signaling pathway suggests their important roles in heterosis of thermal resistance in SD (Fig. 6D). The protein processing in endoplasmic reticulum pathway is a sophisticated quality-control system that play a vital role in adapting to stressful environment conditions [53]. When exposed to heat stress, it could help improve cells survival by enhancing the protein folding capacity in the lumen of the endoplasmic reticulum [54]. The NF- $\kappa \mathrm{B}$ signaling pathway has a critical role in regulating various aspects of the apoptotic program [55]. Heat stress induces cell cytoskeleton reorganization and inflammatory responses. The activation of NF- $\kappa \mathrm{B}$ signaling pathways can protect cells from thermally induced injuries [56]. Mitophagy is an important mitochondrial quality control mechanism that eliminates damaged mitochondria [57]. Acceleration of metabolic processes could trigger damage of mitochondria and apoptosis, by an excessive production of reactive oxygen species [58]. In this study, when exposed to heat stress, elevated temperature can increase oxygen consumption of abalone and produce harmful endproducts, such as reactive oxygen species, superoxide anion, and hydroxyl radical. The activation of mitophagy signaling pathways might ensure proper elimination of dysfunctional mitochondria in abalone. In addition, we found that among these 545 overlap genes, 39 genes had undergone alternative splicing event in $\mathrm{SD}$, which may 
play important roles in heterosis of thermal resistance in SD. In particular, $S y k$ is a key molecule that controls multiple physiological functions in cells. Syk encodes a cytoplasmic kinase that serves for multiple functions within the immune system, to couple receptors for antigens and antigen-antibody complexes to adaptive and innate immune responses [59]. The activation of $S y k$ induces $\mathrm{Ca}^{2+}$ release from intracellular pools through tyrosine phosphorylation of PLC-g2 following oxidative stress [60]. RELis a key factor in the induction of the humoral immune response. The REL/NF- $\mathrm{kB}$ transcription factors, Relish, Dorsal and Dif, are involved in Toll and Imd signal transduction pathways of the innate immune response [61]. In mammals, it is involved in the inflammatory response, whose protein family is also involved in hematopoiesis [62]. In C. gigas, based on homology to other invertebrates' Rel cascade, the function of the oyster pathway may serve to regulate genes involved in innate defense and/or development [63]. In gastropod abalone $(H$. diversicolor supertexta), the Rel homologue had been identified and demonstrated to perform a crucial role in the immune response [64]. In this study, the $R E L$ may be involved in activation of NF- $\kappa \mathrm{B}$ signaling pathway to response for heat stress. SCARB1 is a transmembrane protein belonging to the scavenger receptors family and it plays important role in viral entry and phagocytosis of apoptotic cells [65]. In sharimp (Marsupenaeus japonicus), SCARB1 protects shrimp from bacteria by enhancing phagocytosis and regulating expression of antimicrobial peptides [66]. In Chinese mitten crab (Eriocheir. sinensis), SCARB1 restricts bacteria proliferation by promoting phagocytosis [67]. In our study, SCARB1 was found to be upregulated in heat stress, and its expression level in SD was higher than its parents, which might be one of the reasons for heterosis of abalone. TLR 1 is a member of the Toll-like receptor $(T L R)$ family that form an effective defense against cellular damage and plays a key role in pathogen recognition and innate immune activation [68]. In mammals, TLR1 and TLR2 can recognize exogenous peptidoglycans and lipoproteins, and induce NF- $k \mathrm{~B}$ activation to produce various inflammatory cytokines [69]. In disk abalone $(H$. discus discus), the transcript level of TLR in gill tissues was up-regulated after the stress experiment, indicating that TLR may play a role in the antibacterial and antiviral defense of disk abalone [70]. Due to the effect of alternative splicing, more transcripts were generated in TLR1, which may lead to increased protein polymorphism and had an impact on the abalone. The RNA-seq read counts and estimated exon inclusion level of TLR1genes at control and heat stress group in SD were showed in Fig. 6B. Therefore, the increased expression level of TLR1 may enhance the resistance of abalone. MUC1 is a high-molecular weight $(400 \mathrm{kDa})$, type I membrane-tethered glycoprotein, which has shown to have anti-adhesive and immunosuppressive properties, protects against infections [71]. In this study, in order to respond to heat stress, abalone secreted a large amount of mucus on the body surface for self-protection, the $M U C 1$ may play a role in this process. Certainly, the functions of these genes in abalone need further study.

\section{Conclusions}

The heterosis of thermal resistance in SD was confirmed in this study, by comparing ABTs among the abalones from DD, SS, and SD populations. Then the transcriptome analysis of hybrid abalone SD and its parents DD and SS were conducted using RNA-sequencing. Variations in the alternative splicing genes and the diverse expression patterns of non-additive genes may result in phenotypic and physiological differences in the thermal resistance of hybrid abalone and its parents. We proposed alternative splicing genes and non-additive genes might play important roles on heat tolerance heterosis. Overall, our study shed new insights on the molecular mechanism for heterosis of thermal resistance in the interspecific hybrid abalone SD. These findings might provide some suggestions for further studies of heatresponse mechanisms in mollusks. The key genes or pathways would be great indicator for our follow-up work. Combined these with the results with other studies, such as genome-wide association study (GWAS), gene editing, and proteome, this could help develop thermal-resistant abalones for abalone aquaculture industry.

\section{Materials and methods}

\section{Growth trait comparison experiment}

A total of 180 juvenile abalones of each population (DD, $\mathrm{SS}$, and SD) were selected and divided into three net tanks $(65 \times 40 \times 60 \mathrm{~cm})$ for culture experiments. During the experiment, fresh seawater was constantly injected into the tanks, and the salinity and dissolved oxygen were kept at $32 \mathrm{ppt}$ and $6 \mathrm{mg} / \mathrm{L}$, respectively. All abalones were fed once daily with Gracilaria ameneiformis, and all the residual food particles and fecal debris were removed $24 \mathrm{~h}$ after feeding. A thermometer (HOBO, USA) was used for temperature monitoring during the experiment. The shell length, body weight, and survival rates were measured and recorded every two months. Shell length was measured using Vernier calipers (accuracy, $0.01 \mathrm{~mm}$ ), whereas body weight was measured using an electronic balance (accuracy, $0.01 \mathrm{~g}$ ). Statistical analysis was done with SPSS v24.0. One-way ANOVA was conducted to compare the differences in growth traits among three populations. 


\section{Animal acclimation}

The experimental abalones (SS, DD and hybrid SD) were transported from Fuda Abalone Farm (Jinjiang, China) to the lab for thermal tolerance assessment. Sixty individuals per stock with the same size $(5.5-6.5 \mathrm{~cm})$ were randomly selected and then acclimated in a thermocontrolled seawater recirculating system for seven days. During the acclimation, salinity, dissolved oxygen, and temperature were kept at $32 \mathrm{ppt}, 6 \mathrm{mg} / \mathrm{L}$ and $20^{\circ} \mathrm{C}$, respectively. All abalones were fed once daily with Gracilaria ameneiformis and all the residual food particles and fecal debris were removed $12 \mathrm{~h}$ before the experiment.

\section{ABT of cardiac performance}

The non-invasive Arrhenius break temperatures method $(\mathrm{ABT})$ was used for heart rate measurement described by $[26,28]$. Thirty individuals per population were used to determine ABT. Abalones were placed in a transparent plastic box $(30.0 \times 20.0 \times 15.0 \mathrm{~cm})$, which was immersed in a thermo-controlled water bath. The seawater in the plastic box was aerated and its temperature was increased at a rate of $0.1{ }^{\circ} \mathrm{C} / \mathrm{min}$ from $20^{\circ} \mathrm{C}$. A thermometer (Fluke 54II, Fluke calibration, USA) was used for temperature monitoring.

An infrared sensor was glued (Krazy Glue, Westerville, $\mathrm{OH}$, United States) to the shell above the heart of the abalone. Then the fluctuations of heart beats were amplified, filtered and recorded by an infrared signal amplifier (AMP03, Newshift, Leiria, Portugal) and Powerlab (8/35, ADInstruments, March-Hugstetten, Australia). Heart beat data were monitored and analyzed with software LabChart v8.0. The ABT was defined as the temperature at which the heart rate decreased dramatically, determined by using regression analyses to generate the best fit line on both sides of a putative break point [72]. To construct Arrhenius plots, heart rates were transformed to the natural logarithm of beats $\mathrm{min}^{-1}$. Temperatures are shown as 1000/K (Kelvin temperature). One-way ANOVA was conducted in SPSS v24.0 to compare the differences in ABT among three populations. $P<0.05$ was considered significant in differences.

\section{Heat stress experiment}

The abalones were acclimated at $20{ }^{\circ} \mathrm{C}$ for $7 \mathrm{~d}$ in circulating tank before the experiment. A thermometer (Fluke 54II, Fluke calibration, USA) was used for temperature monitoring during the experiment. To minimize disturbance from the external environment, the room was kept dark during the experiment. For the heat stress experiment, abalones were divided into two groups: the control group $\left(\mathrm{C}, 20^{\circ} \mathrm{C}\right)$ and the heat stress group $(\mathrm{H}$, $\left.30^{\circ} \mathrm{C}\right)$. For the $\mathrm{C}$ group, the water temperature was maintained at $20^{\circ} \mathrm{C}$ in a circulating water system tank during the experiment. For the $\mathrm{H}$ group, the water temperature was rose to $30^{\circ} \mathrm{C}$ at a rate of $1{ }^{\circ} \mathrm{C} / \mathrm{h}$ by heater. The heat exposure time was $2 \mathrm{~h}$. Then three individuals of three populations per group were collected. Gill tissues dissected from abalones were immediately frozen in liquid nitrogen, and finally stored at $-80^{\circ} \mathrm{C}$.

\section{RNA extraction, library construction and high-throughput sequencing}

Total RNA was extracted from the gills of the 18 samples using Trizol reagent (Gibco BRL, United States). To check the purity and integrity of RNA, the NanophotometerR spectrophotometer (IMPLEN, Westlake Village, CA, United States) and RNA Nano 6000 Assay Kit of the Agilent Bioanalyzer 2100 system (Agilent Technologies, Santa Clara, CA, United States) were used. Library preparation and sequencing were performed by Novogene (Beijing, China). RNA-seq libraries were constructed according to the manufacturer's protocol of the Vazyme mRNA-seq library preparation kit (Vazyme) and were sequenced to generate 150-nucleotide paired-end reads on an HiSeq platform (Illumina).

\section{Analysis of differential expressed genes (DEGs) and alternative splicing events}

Raw reads were filtered using fastp [73] with the following parameters: -w 16 -z 6 -q 20 -u 30 -n 10 -l 150. The clean reads were aligned to the reference genome of $H$. discus hannai (DD) (unpublished data) using HISAT2 [74], generating BAM files. The BAM files were sorted using samtools and then used to estimated gene abundances of annotated genes in the reference genome using StringTie [75] with the following parameters: -e B. The gene read counts were extracted using the prepDE.py script included in StringTie, and then taken as input for R DESeq2 package. The gene expression profiles were derived from the TMM normalization of the read counts with rlog transformation using $\mathrm{R}$ DESeq2 package. The differentially expressed genes (DEGs) were identified using R DESeq2 package with a false discovery rate $(\mathrm{FDR})<0.05$ and $\mid \log 2$ FoldChange $\mid>1$. In order to evaluate the effect of interaction of two factors (population and environment), an interaction analysis was implemented using $R$ DESeq2 package with design: population + environment + population: environment, and $p$ adj $<0.05$ and $\mid \log 2$ FoldChange $\mid>1$ as the significance threshold.

To identify AS events in hybrid SD and detect their potential contributes to the heterosis of thermal tolerance, a genome-wide investigation of AS events in the SD and its parents DD and SS were performed by RNAsequencing. Replicate multivariate analysis of transcript splicing (rMATS) v4.0.1 [76] was used to identify 
Table 1 Criteria of gene expression mode in hybrid (for genes are not equally expressed in two parents)

\begin{tabular}{|c|c|c|c|c|c|c|c|}
\hline Category & Overdominance(-) & $\begin{array}{l}\text { Dominance } \\
(-)\end{array}$ & Partial dominance(-) & Additive & Partial dominance(+) & $\begin{array}{l}\text { Dominance } \\
(+)\end{array}$ & Over dominance(+) \\
\hline $\mathrm{d} /|\mathrm{a}|$ & $(-\infty, 1.2)$ & {$[-1.2,-0.8)$} & {$[-0.8,-0.2)$} & {$[-0.2,0.2]$} & $(0.2,0.8]$ & $(0.8,1.2]$ & $(1.2,+\infty]$ \\
\hline
\end{tabular}

differential alternative splicing events between the $\mathrm{C}$ group and the $\mathrm{H}$ group. In each comparison, only the exon junctions with the average aligned reads of six samples greater than 5 remained for the subsequent analysis. Differential alternative splicing events were considered to be significant if the absolute change in "percent spliced in" (denoted as $\Delta \psi$ ) was $\geq 0.1$ with a false discovery rate $(\mathrm{FDR})$ of $<0.05$.

\section{Additive and dominance effect analysis}

A subset of genes, which displayed additive and nonadditive gene expression, referring to the expression levels in a hybrid that were significantly different from the parental values, were obtained (Table 1). The degree of dominance was measured using the ratio $(d /|\mathrm{a}|)$ of the estimated dominance effect over the estimated additive effect:

$$
\frac{d}{|a|}=\frac{\text { hybrid }-0.5 *\left(\text { parent }_{1}+\text { parent }_{2}\right)}{\mid \text { parent }_{1}-\text { parent }_{2} \mid}
$$

The classifications were judged according to [77]: additive $=-0.20$ to 0.20 ; partial dominance $=0.20$ to 0.80 or -0.80 to -0.20 ; dominance $=0.80$ to 1.20 or -1.20 to -0.80 ; overdominance $=>1.20$ or $<-1.20$.

\section{Integrated analysis of DEGs, DAGs, and NAGs}

Integrated analysis was conducted for the common DEGs of three populations and ODO genes of the heat stress group and the DAGs of SD. The Kyoto Encyclopedia of Genes and Genomes (KEGG) pathway enrichment analysis of genes were conducted using $R$ clusterProfiler package [78], based on a modified Fisher's exact test with $p<0.05$ and FDR cutoff $<0.05$.

\section{Abbreviations}

SS: H. gigantea $+\times$ H. gigantea ${ }^{\lambda}$; DD: H. discus hannaiq $\times$ H. discus hannai ô; SD: H. gigantea $+\times H$. discus hannai $\hat{D}^{\text {; }}$ ABT: Arrhenius break temperatures; DEGs: significant differently expressed genes; AS: alternative splicing: DAGs: significant differently alternative splicing genes; NAGs: non-additive genes; Syk: Tyrosine-protein kinase SYK; Rel: Nuclear factor NF-KB p110; TLR1: Toll-like receptor 1; MUC1: Mucin-1; SCARB1: Scavenger receptor class B member 1

\section{Acknowledgements}

Not applicable.

\section{Authors' contributions}

XQZ and HZK conceived of this research, performed data analysis, and drafted the manuscript. SYW drafted the manuscript. XQZ, GY, WY and LX participated in the animal experiments. GSH and LYS performed data analysis. YWW and $\mathrm{KCH}$ participated in the design and coordination the study. All authors have read and approved the final manuscript.

\section{Funding}

This work was supported by grants from National Key Research and Development Program of China (2018YFD0901401), National Natural Science Foundation of China (No. 31872564 and 31802294); Key S \& T Program of Fujian Province (No. 2019 N0001 and 2020NZ08003); Tianjin Seed Industry Science and Technology Major Project (Grant No. 19ZXZYSN00080); and China Agriculture Research System of MOF and MARA.

\section{Availability of data and materials}

The RNA sequencing data used in this study have been uploaded to the National Center for Biotechnology Information (NCBI) as BioprojectID: PRJNA721743. And the SRA accessions were SRR14327194-SRR14327211.

\section{Declarations}

Ethics approval and consent to participate

Not applicable.

\section{Consent for publication}

Not applicable.

\section{Competing interests}

The authors declare that they have no competing interests.

\section{Author details}

${ }^{1}$ State Key Laboratory of Marine Environmental Science, College of Ocean and Earth Sciences, Xiamen University, Xiamen 361102, People's Republic of China. ${ }^{2}$ Fujian Key Laboratory of Genetics and Breeding of Marine Organisms, Xiamen University, Xiamen 361102, People's Republic of China.

Received: 19 April 2021 Accepted: 23 August 2021

Published online: 08 September 2021

\section{References}

1. Shull GH. The composition of a field of maize. J Hered. 1908:4:293-301.

2. Lin T, Zhou C, Chen G, Yu J, Wu W, Ge Y, et al. Heterosis-associated genes confer high yield in super hybrid rice. Theor Appl Genet. 2020;133(12):328797. https://doi.org/10.1007/s00122-020-03669-y.

3. Chen ZJ. Genomic and epigenetic insights into the molecular bases of heterosis. Nat Rev Genet. 2013;14(7):471-82. https://doi.org/10.1038/nrg3503.

4. Zhou G, Chen Y, Yao W, Zhang C, Xie W, Hua J, et al. Genetic composition of yield heterosis in an elite rice hybrid. Proc Natl Acad Sci U S A. 2012; 109(39):15847-52. https://doi.org/10.1073/pnas.1214141109.

5. Shahzad K, Zhang X, Guo L, Qi T, Tang H, Zhang M, et al. Comparative transcriptome analysis of inbred lines and contrasting hybrids reveals overdominance mediate early biomass vigor in hybrid cotton. BMC Genomics. 2020;21(1):140. https://doi.org/10.1186/s12864-020-6561-9.

6. Tian S, Xu X, Zhu X, Wang F, Song X, Zhang T. Overdominance is the major genetic basis of lint yield heterosis in interspecific hybrids between $G$. hirsutum and G. barbadense. Heredity (Edinb). 2019;123(3):384-94.

7. Hochholdinger $F$, Hoecker N. Towards the molecular basis of heterosis. Trends Plant Sci. 2007;12(9):427-32. https://doi.org/10.1016/j.tplants.2007.08.005.

8. Mckeown PC, Fort A, Duszynska D, Sulpice R, Spillane C. Emerging molecular mechanisms for biotechnological harnessing of heterosis in crops. Trends Biotechnol. 2013;31(10):549-51. https://doi.org/10.1016/j. tibtech.2013.06.008.

9. Uzarowska A, Keller B, Piepho HP, Schwarz G, Ingvardsen C, Wenzel G, et al. Comparative expression profiling in meristems of inbred-hybrid triplets of maize based on morphological investigations of heterosis for plant height. Plant Mol Biol. 2007;63(1):21-34. https://doi.org/10.1007/s11103-006-9069-z. 
10. Guo H, Mendrikahy JN, Xie L, Deng J, Lu Z, Wu J, et al. Transcriptome analysis of neo-tetraploid rice reveals specific differential gene expressions associated with fertility and heterosis. Sci Rep. 2017;7(1):40139. https://doi. org/10.1038/srep40139.

11. Zhang C, Lin C, Fu F, Zhong X, Peng B, Yan H, et al. Comparative transcriptome analysis of flower heterosis in two soybean $\mathrm{F} 1$ hybrids by RNA-seq. PLoS One. 2017;12(7):e0181061. https://doi.org/10.1371/journal. pone.0181061.

12. Liu YJ, Gao SQ, Tang YM, Gong J, Zhang X, Wang YB, et al. Transcriptome analysis of wheat seedling and spike tissues in the hybrid Jingmai 8 uncovered genes involved in heterosis. Planta. 2018;247(6):1307-21. https:// doi.org/10.1007/s00425-018-2848-3.

13. Ding $Y$, Zhang $R$, Zhu L, Wang M, Ma $Y$, Yuan D, et al. An enhanced photosynthesis and carbohydrate metabolic capability contributes to heterosis of the cotton (Gossypium hirsutum) hybrid 'Huaza Mian H318', as revealed by genome-wide gene expression analysis. BMC Genomics. 2021; 22(1).

14. Zhang G, Li J, Zhang J, Liang X, Zhang X, Wang T, et al. Integrated analysis of transcriptomic, miRNA and proteomic changes of a novel hybrid yellow catfish uncovers key roles for miRNAs in Heterosis. Mol Cell Proteomics. 2019;18(7):1437-53. https://doi.org/10.1074/mcp.RA118.001297.

15. Yang J, Luo S, Li J, Zheng Z, Du X, Deng Y. Transcriptome analysis of growth heterosis in pearl oyster Pinctada fucata martensii. FEBS Open Bio. 2018;8(11):1794-803. https://doi.org/10.1002/2211-5463.12502.

16. Gao Y, Zhang H, Gao Q, Wang L, Zhang F, Siva VS, et al. Transcriptome analysis of artificial hybrid pufferfish Jiyan-1 and its parental species: implications for pufferfish heterosis. PLoS One. 2013;8(3):e58453. https://doi. org/10.1371/journal.pone.0058453.

17. Wang Z, Cui J, Song J, Wang H, Gao K, Qiu X, et al. Comparative transcriptome analysis reveals growth-related genes in juvenile Chinese Sea cucumber, Russian Sea cucumber, and their hybrids. Mar Biotechnol (NY). 2018;20(2):193-205. https://doi.org/10.1007/s10126-018-9796-6.

18. Chen S, Zhang Z, Ji H, Xu S, Yang Y, Jia C, et al. Transcriptome profiles of F1 hybrids (Acanthopagrus schlegelii ${ }^{-} \times$Pagrus major ㅇ) and parents reveal hybrid effects on individual development. Aquac Res. 2020;51(10):4011-21. https://doi.org/10.1111/are.14744.

19. Wang ET, Sandberg R, Luo S, Khrebtukova I, Zhang L, Mayr C, et al. Alternative isoform regulation in human tissue transcriptomes. Nature. 2008; 456(7221):470-6. https://doi.org/10.1038/nature07509.

20. Reddy AS, Marquez Y, Kalyna M, Barta A. Complexity of the alternative splicing landscape in plants. Plant Cell. 2013;25(10):3657-83. https://doi. org/10.1105/tpc.113.117523.

21. Blencowe BJ. Alternative splicing: new insights from global analyses. Cell. 2006;126(1):37-47. https://doi.org/10.1016/j.cell.2006.06.023.

22. Zhou R, Moshgabadi N, Adams KL. Extensive changes to alternative splicing patterns following allopolyploidy in natural and resynthesized polyploids. Proc Natl Acad Sci U S A. 2011;108(38):16122-7. https://doi.org/10.1073/pna S.1109551108

23. Di Santo V. Ocean acidification exacerbates the impacts of global warming on embryonic little skate, Leucoraja erinacea (Mitchill). J Exp Mar Biol Ecol. 2015;463:72-8. https://doi.org/10.1016/j.jembe.2014.11.006.

24. Morash AJ, Alter K. Effects of environmental and farm stress on abalone physiology: perspectives for abalone aquaculture in the face of global climate change. Rev Aquac. 2016;8(4):342-68. https:/doi.org/10.1111/raq.12097.

25. Lushchak VI. Environmentally induced oxidative stress in aquatic animals. Aquat Toxicol. 2011;101(1):13-30. https://doi.org/10.1016/j.aquatox.2010.10.006.

26. Chen N, Huang Z, Lu C, Shen Y, Luo X, Ke C, et al. Different transcriptomic responses to thermal stress in heat-tolerant and heat-sensitive Pacific abalones indicated by cardiac performance. Front Physiol. 2018;9:1895.

27. Luo $X, W-W$ Y, C-h K, J-x Y, Jie W. Preliminary Studies on Hybridization Between the Abalones Haliotis sieboldii and H. discus discus. Journal of Xiamen University (Natural Science). 2006;45:4.

28. Chen N, Luo X, Gu Y, Han G, Dong Y, You W, Ke C: Assessment of the thermal tolerance of abalone based on cardiac performance in Haliotis discus hannai, H gigantea and their interspecific hybrid. Aquaculture. 2016; 465:258-64.

29. Boamah GA, Wang T, Chowdhury IA, Luo X, Huang M, Xu C, et al. Sub-low salinity impact on survival, growth and meat quality of the Pacific abalone (Haliotis discus hannai) and hybrids. Aquac Res. 2020;51(12):5184-93. https:// doi.org/10.1111/are.14856.
30. Hoegh-Guldberg O, Bruno JF. The impact of climate change on the World's marine ecosystems. Science. 2010;328(5985):1523-8. https://doi.org/10.1126/ science.1189930.

31. Tripp-Valdez MA, Cicala F, Galindo-Sanchez CE, Chacon-Ponce KD, LopezLandavery E, Diaz F, et al. Growth Performance and Transcriptomic Response of Warm-Acclimated Hybrid Abalone Haliotis rufescens (female symbol) x H. corrugata (male symbol). Mar Biotechnol (NY). 2021;23(1):62-76.

32. Shen Y, Huang M, You W, Luo X, Ke C. The survival and respiration response of two abalones under short-term hypoxia challenges. Aquaculture. 2020; 529:735658. https://doi.org/10.1016/j.aquaculture.2020.735658.

33. Alter K, Andrewartha SJ, Morash AJ, Clark TD, Hellicar AD, León RI, et al. Hybrid abalone are more robust to multi-stressor environments than pure parental species. Aquaculture. 2017;478:25-34. https://doi.org/10.1016/j.aqua culture.2017.04.035.

34. Ge X, Chen W, Song S, Wang W, Hu S, Yu J. Transcriptomic profiling of mature embryo from an elite super-hybrid rice LYP9 and its parental lines. BMC Plant Biol. 2008:8(1):114. https://doi.org/10.1186/1471-2229-8-114.

35. Liu H, Chen GB. A new genomic prediction method with additivedominance effects in the least-squares framework. Heredity (Edinb). 2018; 121(2):196-204. https://doi.org/10.1038/s41437-018-0099-5.

36. Shiel BP, Cooke IR, Hall NE, Robinson NA, Strugnell JM. Gene expression differences between abalone that are susceptible and resilient to a simulated heat wave event. Aquaculture. 2020;526:735317. https://doi.org/1 0.1016/j.aquaculture.2020.735317

37. Gleason LU, Burton RS. RNA-seq reveals regional differences in transcriptome response to heat stress in the marine snail Chlorostoma funebralis. Mol Ecol. 2015;24(3):610-27. https://doi.org/10.1111/mec.13047.

38. Chen Z, Farrell AP, Matala A, Narum SR. Mechanisms of thermal adaptation and evolutionary potential of conspecific populations to changing environments. Mol Ecol. 2018;27(3):659-74. https://doi.org/10.1111/mec.14475.

39. Gamazon ER. Alternative splicing and genome evolution. In: elS. 2016:1-6.

40. Hiller M, Huse K, Platzer M, Backofen R. Creation and disruption of protein features by alternative splicing -a novel mechanism to modulate function. Genome Biol. 2005;6(7):R58. https://doi.org/10.1186/gb-2005-6-7-r58.

41. Liu J, Sun N, Liu M, Liu J, Du B, Wang X, et al. An autoregulatory loop controlling Arabidopsis HsfA2 expression: role of heat shock-induced alternative splicing. Plant Physiol. 2013;162(1):512-21. https://doi.org/10.11 04/pp.112.205864.

42. Hu X, Wang H, Li K, Liu X, Liu Z, Wu Y, et al. Genome-wide alternative splicing variation and its potential contribution to maize immature-ear heterosis. The Crop Journal. 2020.

43. Tan S, Wang W, Tian C, Niu D, Zhou T, Jin Y, et al. Heat stress induced alternative splicing in catfish as determined by transcriptome analysis. Comp Biochem Physiol Part D Genomics Proteomics. 2019;29:166-72. https://doi.org/10.1016/j.cbd.2018.11.008.

44. Wang R, Yin P, Ruixia Y, Liu X, Luo L, Xu J. Genome-wide profiling of alternative splicing genes in hybrid poplar (P.albaxP.glandulosa CV.84K) leaves. PLoS One. 2020;15(11):e0241914.

45. Zhao Y, Hu F, Zhang X, Wei Q, Dong J, Bo C, et al. Comparative transcriptome analysis reveals important roles of nonadditive genes in maize hybrid An'nong 591 under heat stress. BMC Plant Biol. 2019;19(1):273. https://doi.org/10.1186/s12870-019-1878-8.

46. Marsan PA, Castiglioni P, Fusari F, Kuiper M, Motto M. Genetic diversity and its relationship to hybrid performance in maize as revealed by RFLP and AFLP markers. Theor Appl Genet. 1998;96(2):219-27. https://doi.org/10.1007/ s001220050730

47. Moll RH, Salhuana WS, Robinson HF. Heterosis and genetic diversity in variety crosses of maize. Crop Sci. 1962;2(3):197-8. https://doi.org/10.2135/ cropsci1962.0011183X000200030005X.

48. Di G, Luo X, You W, Zhao J, Kong X, Ke C. Proteomic analysis of muscle between hybrid abalone and parental lines Haliotis gigantea reeve and Haliotis discus hannai Ino. Heredity (Edinb). 2015;114(6):564-74. https://doi. org/10.1038/hdy.2014.124.

49. Ko DK, Rohozinski D, Song Q, Taylor SH, Juenger TE, Harmon FG, et al. Temporal shift of circadian-mediated gene expression and carbon fixation contributes to biomass Heterosis in maize hybrids. PLoS Genet. 2016;12(7): e1006197. https://doi.org/10.1371/journal.pgen.1006197.

50. Wang J, Tian L, Lee HS, Wei NE, Jiang H, Watson B, et al. Genomewide nonadditive gene regulation in Arabidopsis allotetraploids. Genetics. 2006; 172(1):507-17. https://doi.org/10.1534/genetics.105.047894. 
51. Dai P, Wang H, Xiao G, Liu B. Combining ability and heterosis analysis over two environments in a diallel cross of three families of the clam Meretrix meretrix. Acta Oceanol Sin. 2014;33(10):37-42. https://doi.org/10.1007/ s13131-014-0539-x

52. Hedgecock D, Lin JZ, DeCola S, Haudenschild CD, Meyer E, Manahan DT, et al. Transcriptomic analysis of growth heterosis in larval Pacific oysters (Crassostrea gigas). Proc Natl Acad Sci. 2007;104(7):2313-8. https://doi.org/ 0.1073/pnas.0610880104.

53. Fu C, Liu XX, Yang WW, Zhao CM, Liu J. Enhanced salt tolerance in tomato plants constitutively expressing heat-shock protein in the endoplasmic reticulum. Genet Mol Res. 2016;15(2).

54. Liu JX, Howell SH. Endoplasmic reticulum protein quality control and its relationship to environmental stress responses in plants. Plant Cell. 2010; 22(9):2930-42. https://doi.org/10.1105/tpc.110.078154.

55. Monks NR, Biswas DK, Pardee AB. Blocking anti-apoptosis as a strategy for cancer chemotherapy: NF-kappaB as a target. J Cell Biochem. 2004;92(4): 646-50. https://doi.org/10.1002/jcb.20080.

56. Kretz-Remy C, Munsch B, Arrigo AP. NF kB-dependent transcriptional activation during heat shock recovery. J Biol Chem. 2001;276(47):43723-33. https://doi.org/10.1074/jbc.M010821200.

57. Shirakabe A, Ikeda Y, Sciarretta S, Zablocki DK, Sadoshima J. Aging and autophagy in the heart. Circ Res. 2016;118(10):1563-76. https://doi.org/10.11 61/CIRCRESAHA.116.307474.

58. Kubli DA, Gustafsson AB. Mitochondria and mitophagy: the yin and yang of cell death control. Circ Res. 2012;111(9):1208-21. https://doi.org/10.1161/ CIRCRESAHA.112.265819.

59. Krisenko MO, Higgins RL, Ghosh S, Zhou Q, Trybula JS, Wang WH, et al. Syk is recruited to stress granules and promotes their clearance through autophagy. J Biol Chem. 2015;290(46):27803-15. https://doi.org/10.1074/jbc. M115.642900.

60. Tomoko Takano, Kiyonao Sada, Yamamura H: Role of protein-tyrosine kinase Syk in oxidative stress signaling in B cells. Antioxid Redox Signal 2002, 4.

61. Li F, Wang D, Li S, Yan H, Zhang J, Wang B, et al. A dorsal homolog (FcDorsal) in the Chinese shrimp Fenneropenaeus chinensis is responsive to both bacteria and WSSV challenge. Dev Comp Immunol. 2010;34(8):874-83. https://doi.org/10.1016/j.dci.2010.03.008.

62. Leake CJJ. Hemocytic and Humoral Immunity in Arthropods. 1986;61(4):549.

63. Montagnani C, Kappler C, Reichhart JM, Escoubas JM. Cg-Rel, the first Rel/ NF-kB homolog characterized in a mollusk, the Pacific oyster Crassostrea gigas. FEBS Lett. 2004;561(1-3):75-82. https://doi.org/10.1016/S0014-5793(04 )00124-3.

64. Jiang $Y$, Wu X. Characterization of a Rel $\mathbf{N F}$-kappaB homologue in a gastropod abalone, Haliotis diversicolor supertexta. Dev Comp Immunol. 2007;31(2):121-31. https://doi.org/10.1016/j.dci.2006.05.014.

65. Osada Y, Sunatani T, Kim IS, Nakanishi Y, Shiratsuchi A. Signalling pathway involving GULP, MAPK and Rac1 for SR-Bl-induced phagocytosis of apoptotic cells. J Biochem. 2009;145(3):387-94. https://doi.org/10.1093/jb/ mvn176.

66. Bi WJ, Li DX, Xu YH, Xu S, Li J, Zhao XF, et al. Scavenger receptor B protects shrimp from bacteria by enhancing phagocytosis and regulating expression of antimicrobial peptides. Dev Comp Immunol. 2015;51(1):10-21. https://doi. org/10.1016/j.dci.2015.02.001.

67. Wu YM, Yang L, Li XJ, Li L, Wang Q, Li WW. A class B scavenger receptor from Eriocheir sinensis (EsSR-B1) restricts bacteria proliferation by promoting phagocytosis. Fish Shellfish Immunol. 2017;70:426-36. https://doi.org/10.101 6/j.fsi.2017.09.034.

68. Li Y, Deng SL, Lian ZX, Yu K. Roles of Toll-Like Receptors in Nitroxidative Stress in Mammals. Cells. 2019;8, 6.

69. Shimizu T, Kida Y, Kuwano K. Triacylated lipoproteins derived from mycoplasma pneumoniae activate nuclear factor-kappaB through toll-like receptors 1 and 2. Immunology. 2007;121(4):473-83. https://doi.org/10.1111/ j.1365-2567.2007.02594.x.

70. Elvitigala DA, Premachandra HK, Whang I, Nam BH, Lee J. Molecular insights of the first gastropod TLR counterpart from disk abalone (Haliotis discus discus), revealing its transcriptional modulation under pathogenic stress. Fish Shellfish Immunol. 2013;35(2):334-42. https://doi.org/10.1016/j.fsi.2013.04.031.

71. Apostolopoulos V, Stojanovska L, Gargosky SE. MUC1 (CD227): a multitasked molecule. Cell Mol Life Sci. 2015;72(23):4475-500. https://doi.org/10.1 007/s00018-015-2014-Z

72. STILLMAN JH, SOMERO GN. Adaptation to temperature stress and aerial exposure in congeneric species of intertidal porcelain crabs (genus
Petrolisthes): correlation of physiology, biochemistry and morphology with vertical distribution. J Exp Biol. 1996;199:11.

73. Chen S, Zhou Y, Chen Y, Gu J. Fastp: an ultra-fast all-in-one FASTQ preprocessor. Bioinformatics. 2018;34(17):i884-90. https://doi.org/10.1093/ bioinformatics/bty560

74. Kim D, Langmead B, Salzberg SL. HISAT: a fast spliced aligner with low memory requirements. Nat Methods. 2015;12(4):357-60. https://doi.org/10.1 038/nmeth.3317.

75. Pertea M, Pertea GM, Antonescu CM, Chang TC, Mendell JT, Salzberg SL. StringTie enables improved reconstruction of a transcriptome from RNA-seq reads. Nat Biotechnol. 2015;33(3):290-5. https://doi.org/10.1038/nbt.3122.

76. Shen S, Park JW, Lu ZX, Lin L, Henry MD, Wu YN, et al. rMATS: robust and flexible detection of differential alternative splicing from replicate RNA-Seq data. Proc Natl Acad Sci U S A. 2014;111(51):E5593-601. https://doi.org/10.1 073/pnas.1419161111.

77. Stuber CW, Edwards MD, Wendel JF. Molecular marker-facilitated investigations of quantitative trait loci in maize. II Factors Influencing Yield and Its Component Traits. Crop Science. 1987;27:10.

78. Yu G, Wang LG, Han Y, He QY. ClusterProfiler: an R package for comparing biological themes among gene clusters. OMICS. 2012;16(5):284-7. https:// doi.org/10.1089/omi.2011.0118.

\section{Publisher's Note}

Springer Nature remains neutral with regard to jurisdictional claims in published maps and institutional affiliations.
Ready to submit your research? Choose BMC and benefit from:

- fast, convenient online submission

- thorough peer review by experienced researchers in your field

- rapid publication on acceptance

- support for research data, including large and complex data types

- gold Open Access which fosters wider collaboration and increased citations

- maximum visibility for your research: over $100 \mathrm{M}$ website views per year

At $\mathrm{BMC}$, research is always in progress.

Learn more biomedcentral.com/submissions 